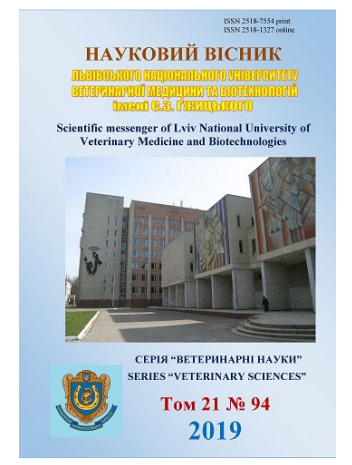

\author{
Науковий вісник Дьвівського національного університету \\ ветеринарної медицини та біотехнологій імені С.З. Гжицького. \\ Серія: Ветеринарні науки \\ Scientific Messenger of Lviv National University \\ of Veterinary Medicine and Biotechnologies. \\ Series: Veterinary sciences
}

\title{
Comparative effectiveness of different therapeutic methods for calves with abomazoenteritis
}

\author{
L.G. Slivinska, S.K. Demydjuk, B.O. Lukashchuk, H.O. Zinko \\ Stepan Gzhytskyi National University of Veterinary Medicine and Biotechnologies Lviv, Ukraine
}

Article info

Received 20.03.2019

Received in revised form 22.04.2019

Accepted 23.04.2019

Stepan Gzhytskyi National University of Veterinary Medicine and Biotechnologies Lviv, Pekarska Str., 50, Lviv, 79010, Ukraine. Tel.: +38-098-586-48-84 E-mail:terapiavet@ukr.net
Slivinska, L.G., Demydjuk, S.K., Lukashchuk, B.O., \& Zinko, H.O. (2019). Comparative effectiveness of different therapeutic methods for calves with abomazoenteritis. Scientific Messenger of Lviv National University of Veterinary Medicine and Biotechnologies. Series: Veterinary sciences, 21(94), 20-24. doi: 10.32718/nvlvet9404

The article presents the results of the comparative effectivness of different treatment regimens of calves with abomazoenteritis. Three groups of black-and-white-breed calves of the age of 1-1.5 months were formed for 5 animals in each of the 1 st and 2 nd experimental (patients with abomazoenteritis) and control - clinically healthy animals. Treatment of sick calves in experimental groups was performed using diet therapy, antimicrobial and rehydration therapy. Animals of the second experimental group, in addition, used detoxification means and Sel-Plex. It was found that calving treatment with the use of diet, antimicrobial, detoxication, rehydration therapy helped to eliminate the main clinical symptoms of the disease. Positive changes were established during laboratory blood tests: the number of red blood cells, leukocytes, hemoglobin, total protein and hematocrit was normalized. In animals with abomazoenteritis, during treatment decreased the activity of transaminases decreased, the content of TBA-active products and medium-weight molecules. The treatment was effective and contributed to a reduction in the duration of their clinical recovery, but the normalization of biochemical parameters was more pronounced in animals of the second experimental group. Application together with antimicrobial and rehydration means of Sel-Plex and detoxification drugs accelerated the restoration of basic biochemical parameters (aspartate aminotransferase, alanine aminotransferase, TBK-active products and medium-weight molecules) to normal, and therefore reduced the metabolic intoxication of the animals organism.

Key words: calves, abomazoenteritis, alanine aminotransferase, aspartate aminotransferase, peroxide lipid oxidation, metabolic intoxication.

\section{Порівняльна ефективність різних способів лікування телят за абомазоентериту}

Л.Г. Слівінська, С.К. Демидюк, Б.О. Лукащук, Г.О. Зінко

Львівський національний університет ветеринарної медицини та біотехнологій імені С.3. Гжицького, м. Львів, Україна

У статті наведені результати порівняльної ефективності різних схем лікування телят, хворих на абомазоентерит. Дослідження проводилися на телятах чорно-рябої породи віком 1-1,5 місячя. Було сформовано 2 - дві дослідні (хворі на абомазоентерит) і контрольна (клінічно здорові) групи по 5 тварини у кожній. Лікування хворих телят дослідних груп проводили з застосуванням дієтотерапії, антимікробної та регідратаційної терапії. Тваринам другої дослідної групи, окрім того, застосовували дезінтокаційні засоби та селеновмісний препарат Сел-Плкс. Встановлено, що проведене лікування телят з використанням дієти, антимікробних, антититоксичних, регідратаційних засобів сприяло усуненню основних клінічних симптомів хвороби. Позитивні зміни встановлені при лабораторному дослідженні крові: нормалізувалася кількість еритроцитів, лейкоцитів, вміст гемоглобіну, загального протеїну та гематокритна величина. У хворих тварин в процесі лікування знижувалася активність трансаміназ, зме- 
ншувався вміст ТБК-активних продуктів і молекул середньої маси. Застосоване лікування було ефективним і сприяло скороченню терміну їхнього клінічного одужання, проте нормалізачія біохімічних показників (аспартатамінотрансферази, аланінамінотрансферази, ТБК-активних продуктів та молекул середньої маси) була більш виражена у тварин другої дослідної групи. Отже, застосування поряд з антимікробними та регідратаційними засобами імуностимулюючих та дезінтокаційних препаратів прискорило відновлення основних біохімічних показників до норми, а отже і зменшувало метаболічну інтоксикацію організму тварин.

Ключові слова: телята, абомазоентерит, аланінамінотрансфераза, аспартатамінотрансфераза, перекисне окиснення ліпідів, метаболічна інтоксикація.

\section{Вступ}

Одним з важливих завдань у сучасному тваринництві $€$ підвищення життєздатності тварин на різних етапах розвитку. Проте збереження молодняку та реалізація генетичного потенціалу стада можливі лише за своєчасного і ефективного комплексного підходу до профілактики та лікування.

Серед захворювань молодняку великої рогатої худоби незаразної етіології вагоме місце займає патологія органів травлення, зокрема абомазоентерит. Встановлено (Piatnychko et al., 2013; Aghakeshmiri et al., 2017; Zinko, 2017; Tsukano \& Suzuki, 2019), що у хворих на абомазоентерит телят, поряд 3 порушенням моторної, секреторної та всмоктувальної функцій слизової оболонки сичуга та кишечнику, загальна інтоксикація та імунний дефіцит є провідними чинниками в розвитку захворювання, що проявляється порушенням роботи печінки, нирок та інших ланок метаболізму. Одним із механізмів, що впливають на імунний статус організму та відіграють роль універсальної неспецифічної патогенетичної ланки різних захворювань $є$ стан системи пероксидного окиснення ліпідів і антиоксидантного захисту (ПОЛ-АОЗ) (Zharkoj, 2004).

Абомазоентерит розглядають як поліетіологічне захворювання, оскільки у його виникненні бере участь ряд факторів, серед яких фізіологічні, технологічні, інфекційні, екологічні та генетичні (Belko et al., 2008; Berezovskyi et al., 2016). Основними причинами виникнення абомазоентериту є порушення умов годівлі: використання неякісного молока та зіпсованих кормів, різкий перехід на рослинні корми; нераціональне застосування замінників цільного молока, поїдання тваринами мінеральних добрив, інших отруйних речовин та ін.

В етіології шлунково-кишкових хвороб телят важливу роль відіграє також дисбактеріоз, що характеризується стійкими кількісними та якісними змінами фізіологічної нормофлори (Kurtiak et al., 2018). Відомо, що шлунково-кишкові захворювання молодняку великої рогатої худоби часто перебігають за типом асоційованої інфекції (Piatnychko et al., 2013; Kurtiak et al., 2018).

Незважаючи на те, що цьому питанню присвячено багато праць (Piatnychko et al., 2013; Teixeira et al., 2015; Zinko \& Slivinska, 2015; Stetsko et al., 2018; Slobodiuk, 2018), захворювання часто протікає з значним охопленням поголів'я та завдає значних економічних збитків тваринництву через зменшення приростів, збільшення витрат на лікування, вибраковку та загибель тварин. У тварин, які перехворіли, знижується імунний захист, що робить їх в подальшому сприйня- тливими до інших захворювань інфекційної і незаразної етіології (Aghakeshmiri et al., 2017; Zinko, 2017; Tsukano \& Suzuki, 2019).

Отже, виникає потреба додаткового вивчення патогенезу абомазоентериту та вдосконалення методів лікування хворих телят 3 урахуванням виявлених метаболічних порушень.

Метою досліджень були розробка і впровадження різних схем лікування та визначення їхньої порівняльної ефективності.

\section{Матеріал і методи досліджень}

Дослідження проводилися на базі СВК імені Лесі Українки Дубенського району Рівненської області та кафедри внутрішніх хвороб тварин та клінічної діагностики Львівського національного університету ветеринарної медицини та біотехнологій імені C.3. Гжицького.

Для досліду було сформовано три дослідні групи телят чорно-рябої породи віком 1-1,5 місяця (контрольну і 2 дослідних). Телята дослідних груп були хворі на абомазоентерит, контрольної - клінічно здорові. Хворих тварин відбирали за принципом аналогів (із врахуванням перебігу хвороби, результатів клінічного дослідження).

Перша група - телята, яких лікували за схемою, що включала використання дієти, антимікробної (енрофлоксацин 50 в дозі 1 мл на 20 кілограм маси тварини) та регідратаційної терапії ( $0,9 \%$ розчин натрію хлориду з урахуванням ступеня зневоднення).

Друга група - телята, яких лікували з використанням дієти, антимікробної (енрофлоксацин 50 в дозі 1 мл на 20 кілограм маси тварини), антитоксичної (фітосорбент в дозі 5 г внутрішньо, один раз на добу), Сел-Плекс по 0,5 г на тварину перорально один раз на добу та регідратаційної терапії (розчин Рінгера-Лока 3 врахуваням ступеня зневоднення).

Сел-Плекс - джерело органічного селену, що синтезується спеціальними штамами дріжджів та володіє антиоксидантними та імуномодулюючими властивостями.

Матеріалом для досліджень була кров хворих тварин, отримана 3 яремної вени (vena jugularis) до та після лікування (на 7-й день дослідження).

У стабілізованій ЕДТА крові підраховували кількість лейкоцитів, еритроцитів та визначали вміст гемоглобіну за допомогою автоматичного гематологічного аналізатора Orphee Mythic 18 (Швейцарія) 3 використанням реагентів фірми PZ Cormay S.A. (Польща).

У сироватці крові визначали вміст загального протеїну, активність амінотрансфераз за допомогою ав- 
томатичного біохімічного аналізатора Mindray BS120 (Китай) 3 використанням реагентів фірми PZ Cormay S.A. (Польща). ТБК-активні продукти - за Uchiyata M., Michara М. в модифікації Л.И. Андреевой с соавт. (Andreeva et al., 1988); молекули середньої маси (МСM) (за В.В. Николайчик, В.М. Моин) (Nikolajchik et al., 1991).

Контроль клінічного статусу телят проводили щодобово впродовж дослідного періоду за загальноприйнятими методиками.

Отримані результати експериментальних досліджень були опрацьовані стандартними методами математичної статистики з використанням програмного забезпечення Microsoft Excel. Вірогідність показників оцінювали за критерієм Стьюдента.

При виконанні експериментальних досліджень дисертаційної роботи всі маніпуляції з телятами, які були задіяні в експерименті, проводили згідно з Свропейською конвенцією "Про захист хребетних тварин, які використовуються для експериментальних і наукових цілей” (м. Страсбург, 1986 р.) і “Загальних етичних принципів експериментів на тваринах”, ухвалених Першим Національним конгресом 3 біоетики (м. Київ, 2001) та дотриманням принципів гуманності, викладеними у директиві Європейської Спільноти (Directive 2010/63).

\section{Результати та їх обговорення}

За клінічного дослідження телят, хворих на абомазоентерит, спостерігали пригнічення різного ступеня, залежування, зниження або відсутність апетиту, тахікардію $(93,3 \pm 1,54$ уд/хв), тахіпное $(37,8 \pm 1,41$ дих. рух./хв), іноді (у $30 \%$ випадків) субфебрильну температуру тіла. У тварин виявляли зниження еластичності шкіри, сухість видимих слизових оболонок та носового дзеркала. У $60 \%$ тварин живіт підтягнутий, черевні стінки напружені. За пальпації - болючість черевної стінки в ділянці сичуга та тонкого кишечнику; за аускультації у 90\% - посилення перистальтичних шумів. У 70\% хворих - гіпотонія передшлунків.

У хворих телят діагностували діарею, кал спочатку був кашоподібної консистенції, надалі ставав рідким, жовто-коричневого до жовто-сірого забарвлення, $з$ домішками неперетравного корму, слизу та пухирців газів, неприємного кислого запаху. У важких випадках (у 30\% випадків) анальний сфінктер послаблений, задня частина тулуба забруднена каловими масами.

Встановлено, що у телят, хворих на абомазоентерит (табл. 1) вміст гемоглобіну був більшим ніж у здорових тварин на $17,5 \%$ (P $<0,01)$, гематокритна величина на $32,6 \%$ (0,001), кількість еритроцитів на 35,1\% (P < 0,001) а загального протеїну (рис. 1$)$ на 7,0\% (Р < 0,01). Ймовірно, що дані зміни були результатом дегідратації організму тварин, що виникла в результаті діареї.

В процесі лікування у телят обох дослідних груп дані показники нормалізувалися та уже на кінець досліджень вірогідно не відрізнялися від аналогічних показників у клінічно здорових тварин.

\section{Таблиця 1}

Показники еритропоезу досліджуваних телят, $(\mathrm{M} \pm \mathrm{m}, \mathrm{n}=5)$

\begin{tabular}{crrrrc}
\hline \multirow{2}{*}{ Показник } & \multicolumn{3}{c}{ Групи тварин } \\
\cline { 2 - 6 } & Клінічно & \multicolumn{2}{c}{ І дослідна } & \multicolumn{2}{c}{ II дослідна } \\
\cline { 2 - 6 } здорові & До лікування & Після лікування & До лікування & Після лікування \\
\hline Гемоглобін, Г/л & $109,0 \pm 3,72$ & $127,9 \pm 1,87$ & $108,3 \pm 2,68^{* *}$ & $128,4 \pm 1,78$ & $108,2 \pm 1,92^{* *}$ \\
Гематокритна & $34,4 \pm 0,93$ & $45,4 \pm 1,47$ & $35,2 \pm 0,86^{* *}$ & $45,8 \pm 1,28$ & $37,0 \pm 1,00$ \\
величина, \% & $5,7 \pm 0,27$ & $7,8 \pm 0,26$ & $5,7 \pm 0,23 * *$ & $7,6 \pm 0,30$ & $5,9 \pm 0,22 *$ \\
Еритроцити, Т/л & &
\end{tabular}

Примітка: * $-\mathrm{P}<0,01 ; * *-\mathrm{P}<0,001$ порівняно 3 початком лікування

Вміст лейкоцитів у хворих тварин становив $12,0 \pm$ 0,41 Г/л і був на 51,9\% більшим (P <0,001), ніж у здорових тварин $(7,9 \pm 0,58$ Г/л). В процесі лікування даний показник нормалізувався i на кінець дослі- дження становив 9,0 $\pm 0,37$ та 8,2 $\pm 0,29$ Г/л, що менше на 23,7 ( $\mathrm{P}<0,01)$ та 32,8\% (P < 0,001) менше, ніж на початку лікування, відповідно у 1-й та 2-й дослідних групах.

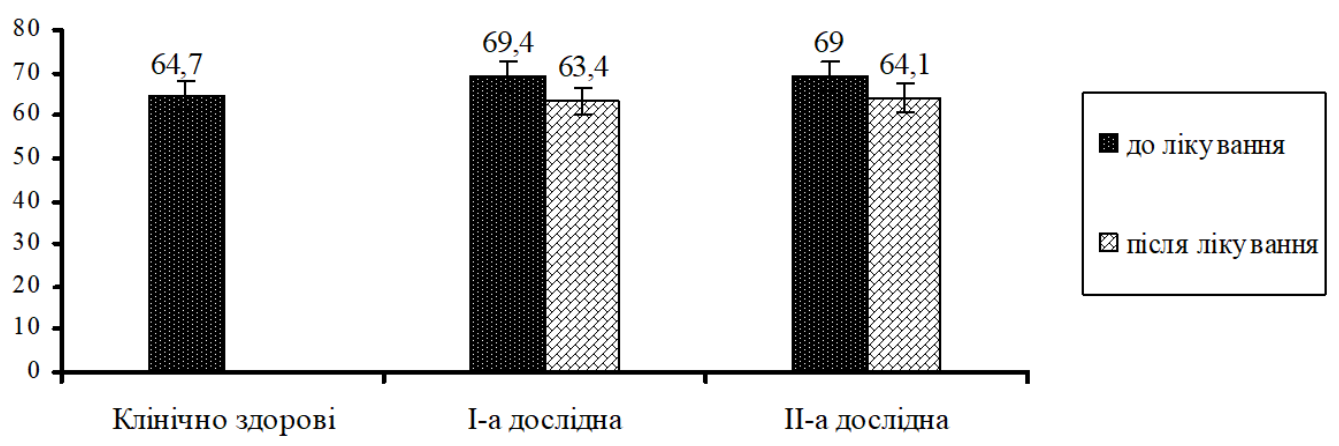

Рис. 1. Вміст загального протеїну у сироватці крові досліджуваних телят, г/л $(\mathrm{n}=5)$ 
Перекисне окиснення ліпідів (ПОЛ) - неспецифічний процес, що є відповідною реакцією на стресові чинники будь-якого генезу а процесі адаптації клітини за дії зовнішніх факторів. Первинні продукти ПОЛ гідропероксиди ліпідів - $\epsilon$ речовинами нестійкими, досить швидко руйнуються 3 утворенням вторинних продуктів пероксидного окиснення, серед яких найбільш відомий малоновий диальдегід, що належить до ТБК-активних продуктів (Danchuk, 2006). Встановлено, що у хворих на абомазоентерит телят вміст ТБКактивних продуктів був більшим, ніж у клінінічно здорових, на 75,0\% (0,001).

Накопичення ТБК-активних продуктів в організмі пояснює формування синдрому метаболічної (ендогенної) інтоксикації, що проявляється накопиченням молекул середньої маси (МСM) і супроводжує багато захворювань внутрішніх органів. МСМ - речовини 3 молекулярною масою від 300 до 5000 дальтон утво- рюються в організмі внаслідок окисної модифікації протеїнів і чинять високу токсичну дію на клітини печінки, нирок, нейрони головного мозку (Karimov, 2005). Встановлено, що МСМ у хворих телят був більшим на 70,3\%, ніж у здорових тварин.

У хворих тварин встановлено підвищення активності ензимів (Р < 0,001) - аланінамінотрансферази (АлАТ) та аспартатамінотрансферази (АсАТ) відповідно на 36,9 та 70,4\% у сироватці крові хворих телят (табл. 3), що, ймовірно, є наслідком ураження гепатоцитів продуктами пероксидного окиснення ліпідів (ПОЛ) та МСМ.

В процесі лікування тварин дані показники відновлювалися, проте на кінець досліджень вміст ТБКактивних продуктів та МСМ були більшими у 1-й дослідній групі відповідно на 25,7 (Р < 0,01) та 20,9 $(\mathrm{P}<0,05) \%$, ніж у клінічно здорових тварин.

Таблиця 2

Вміст ТБК-активних продуктів та МСМ у сироватці крові досліджуваних телят, $(\mathrm{M} \pm \mathrm{m}, \mathrm{n}=5)$

\begin{tabular}{|c|c|c|c|c|c|}
\hline \multirow{3}{*}{ Показник } & \multicolumn{5}{|c|}{ Групи тварин } \\
\hline & \multirow{2}{*}{$\begin{array}{c}\text { Клінічно } \\
\text { здорові }\end{array}$} & \multicolumn{2}{|c|}{ I дослідна } & \multicolumn{2}{|c|}{ II дослідна } \\
\hline & & До лікування & Після лікування & До лікування & Після лікування \\
\hline $\begin{array}{c}\text { ТБК-активні продукти, } \\
\text { ммоль/л }\end{array}$ & $3,2 \pm 0,16$ & $5,4 \pm 0,12$ & $4,4 \pm 0,18^{* *}$ & $5,7 \pm 0,16$ & $3,5 \pm 0,18 * * *$ \\
\hline MCM, г/л & $0,37 \pm 0,022$ & $0,63 \pm 0,027$ & $0,52 \pm 0,033^{*}$ & $0,63 \pm 0,033$ & $0,43 \pm 0,023 * * *$ \\
\hline
\end{tabular}

Примітка: *-P $<0,01 ; * *-\mathrm{P}<0,001$ порівняно $з$ початком лікування

Таблиця 3

Активність амінотрансфераз сироватки крові досліджуваних телят (M \pm m, n = 5)

\begin{tabular}{|c|c|c|c|c|c|}
\hline \multirow{3}{*}{ Показник } & \multicolumn{5}{|c|}{ Групи тварин } \\
\hline & \multirow{2}{*}{$\begin{array}{c}\text { Клінічно } \\
\text { здорові }\end{array}$} & \multicolumn{2}{|c|}{ I дослідна } & \multicolumn{2}{|c|}{ II дослідна } \\
\hline & & До лікування & Після лікування & До лікування & Після лікування \\
\hline АлАТ, ОД/л & $14,1 \pm 0,50$ & $19,0 \pm 1,07$ & $17,5 \pm 0,86$ & $19,5 \pm 1,12$ & $15,0 \pm 0,99 * *$ \\
\hline АсАТ,ОД/л & $41,5 \pm 1,82$ & $70,3 \pm 2,39$ & $67,6 \pm 2,26$ & $71,0 \pm 2,43$ & $49,5 \pm 2,57 * * *$ \\
\hline
\end{tabular}

Примітка: *-P <0,01;**-P $<0,001$ порівняно 3 початком лікування

Встановлено, що активність амінотрансфераз швидше знижувалася у другій дослідній групі. Так, на кінець досліджень встановлено, що у 1-й дослідній групі активність АлАТ була вищою на 16,7\%, а АсАТ на 36,6\% (P < 0,001), ніж у 2-й.

Лікування тварин згідно з розробленими схемами сприяло поліпшенню клінічного стану та відновленню показників крові. Клінічні симптоми у хворих телят зникали на 6-7 добу у 1-й, та на 5-6 у 2-й дослідній групі.

\section{Висновки}

Кращий терапевтичний ефект встановили у телят 2-ї дослідної групи де застосовували дієту, антимікробну, регідратаційну і антитоксичну терапію та селеновмісного препарату Сел-Плекс, про що свідчить відновлення активності амінотрансфераз, вмісту ТБКактивних продуктів та молекул середньої маси, а також скорочення терміну клінічного одужання.

\section{References}

Aghakeshmiri, F., Azizzadeh, M., Farzaneh, N., \& Gorjidooz, M. (2017). Effects of neonatal diarrhea and other conditions on subsequent productive and reproductive performance of heifer calves. Vet Res Commun, 41(2), 107-112. doi: 10.1007/s11259-0179678-9.

Andreeva, L.I., Kozhemjakin, L.A., \& Kishkun, A.A. (1988). Modifikacija metoda opredelenija lipidov v teste s tiobarbiturovoj kislotoj. Laboratornoe delo, 11, 41-43 (in Russian).

Belko, A.A., Shparkovich, M.V., \& Pajterova, V.V. (2008). Osobennosti klinicheskogo projavlenija abomazojenterita u teljat. Visnik Bilocerkiv. derzh. agrar. un-tu: zb. nauk. prac'. Bila Cerkva, 56, 22-26 (in Russian).

Berezovskyi, A.V., Fotina, T.I., Ulko, L.H., Nechyporenko, O.L., \& Titov, Ye.M. (2016). Etiolohichna struktura hostrykh shlunkovo-kyshkovykh zakhvoriuvan teliat, Naukovyi visnyk LNUVMBT imeni S.Z. 
Gzhytskoho, $\quad$ 3(71), $\quad$ 148-151. doi: $10.15421 /$ nvlvet7133 (in Ukrainian).

Danchuk, V.V. (2006). Peroksydne okysnennia u silskohospodarskykh tvaryn i ptytsi. KamianetsPodilskyi: Abetka (in Ukrainian).

Directive 2010/63/eu of the european parliament and of the council of 22 September 2010 on the protection of animals used for scientific purposes. Official Journal of the European Union. L276/33. 20.10.2010. https://eur-lex.europa.eu/legalcontent/EN/TXT/?uri=celex\%3A32010L0063.

Karimov, I.Z. (2005). Okislitel'naja modifikacija belkov i perekisnoe okislenie lipidov $\mathrm{V}$ razvitii metabolicheskoj intoksikacii pri patologii. Lab. Diagnostika, 31(1), 7-13 (in Russian).

Kurtiak, B.M., Romanovych, M.S., Pundiak, T.O., Romanovych, L.V., Sobko, H.V., Romanovych, M.M. (2018). Umovno patohenna mikroflora ta yii rol v etiolohii hostrykh rozladiv travlennia z oznakamy diarei novonarodzhenykh teliat. Naukovyi visnyk LNUVMB imeni S.Z. Gzhytskoho, 20(83), 304-307. doi: 10.15421 nvevet8361 (in Ukrainian).

Nikolajchik, V.V., Moin, V.M., Kirkovskij, V.V. i dr. (1991). Sposob opredelenija "srednih molekul". Lab. Delo, 10, 13-18 (in Russian).

Piatnychko, O.M., Lisova, N.E., Shkodiak, N.V. ta in (2013). Morfolohichni, imunolohichni ta biokhimichni pokaznyky krovi khvorykh na hastroenteryt teliat za umov anty-biotykoterapii. Vet. Medytsyna, 97, 342344. https://elibrary.ru/item.asp?id=22268134 (in Ukrainian).

Slobodiuk, N.M. (2018). Zastosuvannia fluorkhinoloniv u praktytsi veterynarnoi medytsyny Ukrainy. Naukovyi visnyk LNUVMB imeni S.Z. Gzhytskoho, 20(87), 8993. doi: 10.32718 nvevet9210 (in Ukrainian).

Stetsko, T.O. Muzyka, V.P. \& Hunchak, V.M. (2018). Krytychno vazhlyvi antymikrobni preparaty dlia veterynarnoi medytsyny. Naukovyi visnyk LNUVMB imeni S.Z. Gzhytskoho, 20(87), 19-26. doi: 10.15421 nvevet8704 (in Ukrainian).

Teixeira, A.G., Stephens, L., Divers, T.J., Stokol, T., \& Bicalho, R.C. (2015). Effect of crofelemer extract on severity and consistency of experimentally induced enterotoxigenic Escherichia coli diarrhea in newborn Holstein calves. J Dairy Sci., 98(11), 8035-8043. doi: 10.3168/jds.2015-9513.

Tsukano, K., \& Suzuki, K. (2019). Plasma amino acid abnormalities in calves with diarrhea. J Vet Med Sci., 81(4), 517-521. doi: 10.1292/jvms.18-0645.

Zharkoj, B.L. (2004). Vzaimosvjaz' intensivnosti processov svobodno $\neg$ radikal'nogo okislenija i pokazatelej immunnogo statusa u teljat. Svobodnye radikaly, antioksidanty i zdorov'e zhivotnyh : mate-rialy mezhdunar. nauch.-prakt.konf., 21-23 sentjabrja 2004 g. Voronezh, 36-40 (in Russian).

Zinko, H.O. (2017). Imunnyi status teliat, khvorykh na hastroenteryt. Naukovyi visnyk LNUVMB imeni S.Z. Gzhytskoho, 19(82), 61-65. doi: 10.15421/nvlvet8213 (in Ukrainian).

Zinko, H.O. (2017). Peroksydno-okysni protsesy ta stan systemy antyoksydantnoho zakhystu u teliat za hastroen-terytu. Ahrarnyi visnyk Prychornomoria. Veterynarni nauky, 83, 86-90 (in Ukrainian).

Zinko, H.O., \& Slivinska, L.H. (2015). Vplyv preparativ Selenu ta Hermaniiu na okremi lanky patohenezu hastroenterytu u teliat. Biolohiia tvaryn, 17(2), 57-64. doi: 10.15407/animbiol17.02 (in Ukrainian). 